\title{
Pharmacobotanic characterization of young stems and stem barks of Rauvolfia sellowii Müll. Arg., Apocynaceae
}

\author{
Leopoldo Clemente Baratto, Márcia do Rocio Duarte, Cid Aimbiré de Moraes Santos*
}

Pharmacognosy Laboratory, Department of Pharmacy, Federal University of Paraná

\begin{abstract}
Rauvolfia sellowii Müll. Arg. (Apocynaceae), a Brazilian native tree rich in indole alkaloids, is known as "pau-pra-tudo" and popularly used as hypocholesterolemic, hypoglycemic and antihypertensive. The aim of this work was to study the anatomy of the young stems and stem barks of this medicinal plant, in order to contribute to the identification of the species as a drug. The plant material was fixed and prepared according to standard microtechniques. The young stems have remaining epidermis, but a suberified peridermis is evident. The phellogen is located in the cortical region, forming suber externally. Underneath the phellogen, lies the phelloderm and collenchymatic region. In the cortex, there are numerous laticifers and some fibers. There is an incomplete sclerenchymatic sheath, consisting of several groups of fibers and stone cells. The stem has internal phloem ordered as isolated groups side by side. Numerous laticifers, calcium oxalate crystals, idioblasts and amyloplasts are found in the cortex, phloem, xylem and pith. The stem bark has many layers of suber and cortical parenchyma, a sheath composed of fibers and stone cells totally lignified, and external phloem. These anatomical characteristic, taken together, can be used as quality control parameters for this species.
\end{abstract}

Uniterms: Rauvolfia sellowii/pharmacognosy. Apocynaceae/pharmacognosy. Medicinal plants. Vegetal anatomy. Internal phloem. Laticiferous ducts. Calcium oxalate crystals.

Rauvolfia sellowii Müll. Arg. (Apocynaceae), uma árvore nativa brasileira rica em alcaloides indólicos, é conhecida como "pau-pra-tudo" e utilizada popularmente como hipocolesterolêmica, hipoglicêmica e anti-hipertensiva. O presente trabalho teve como objetivo caracterizar anatomicamente o caule jovem e a casca caulinar dessa planta medicinal, a fim de contribuir para a identificação e autenticidade da droga. $\mathrm{O}$ material vegetal foi fixado e submetido às microtécnicas usuais. $\mathrm{O}$ caule jovem possui epiderme remanescente, porém uma periderme suberificada é observada. O felogênio instala-se na região cortical, formando súber externamente. Subjacentes ao felogênio são observadas a feloderme e uma região colenquimática. No córtex, há numerosos laticíferos e algumas fibras. Há uma bainha esclerenquimática incompleta, constituída de vários grupos de fibras e células pétreas. O caule mostra floema interno organizado em grupos isolados lado a lado. Numerosos laticíferos, cristais de oxalato de cálcio, idioblastos e amiloplastos são encontrados no córtex, no floema, no xilema e na medula. A casca do caule possui várias camadas de súber e parênquima cortical, uma bainha composta de fibras e células pétreas totalmente lignificadas, e floema externo. Estes caracteres anatômicos, quando analisados em conjunto, podem ser utilizados como parâmetros para controle de qualidade desta espécie.

Unitermos: Rauvolfia sellowii/farmacognosia. Apocynaceae/farmacognosia. Plantas medicinais. Anatomia vegetal. Floema interno. Laticíferos. Cristais de oxalato de cálcio.

\section{INTRODUCTION}

The Rauvolfia L. genus belongs to the Apocynaceae family and grows widely around all tropical regions of

\footnotetext{
*Correspondence: C. A. M. Santos. Laboratório de Farmacognosia, Departamento de Farmácia, Universidade Federal do Paraná. Av. Pref. Lothário Meissner, 632, Jardim Botânico - 80210-170 - Curitiba - PR, Brasil. E-mail: cid@ufpr.br
}

the world. There are around seventy species, 31 of which are distributed in South America, mainly in Brazil (Koch, 2002). The species of the genus are characterized mainly by the presence of indole alkaloids (Mandinaveitia et al., 1995) and most have carbon chains of the ajmaline, reserpine and yohimbine types (Carlos, 2007). These alkaloids are found in the leaves, stems, stem barks and 
roots (Djerassi et al., 1957; Lacobucci, Deulofeu, 1957; Mandinaveitia et al., 1995; Hanhinen, Lounasmaa, 2001; Kato, 2001; Cancelieri et al., 2002; Kato et al., 2002; Carlos, 2007), and several pharmacological activities have been described for the genus, particularly for the stem barks, such as antimicrobial (Rastogi et al., 1998; Tona et al., 1998; Carlos, 2007; Pesewu et al., 2008), antitumoral (Kato, 2001), antiepileptic (Quintans-Júnior et al., 2007), antidiabetic, healing (Campbell et al., 2006), antiophidic and antihypertensive (Koch, 2002).

Rauvolfia sellowii Müll. Arg. (Figures 1 to 3 ) is a Brazilian native tree that can reach up to $15 \mathrm{~m}$ in height. It is found in the forests of South and Southeast Brazil, Paraguay and Argentine. The species, popularly known as "casca-d'anta", "jasmin-grado" or "pau-pra-tudo", has leaves, stems and stem barks used traditionally to reduce glucose and cholesterol blood levels (Rech et al., 1998; Koch, 2002; Silva et al., 2004). The root is used as an antihypertensive (Batista et al., 1996). While the alkaloids sellowiine, raucaffrinoline, perakine, vomilenine, 12-demethoxy-tabernulosine, $19 \alpha, 20 \alpha$-epoxy-akuamicine (Batista et al., 1996) were found in the leaves of $R$. sellowii, ajmaline and aricin have been described as the main compounds in the roots, along with traces of reserpine, ajmalicine, tetra-hydroalstonine (Hochstein, 1955), tetraphyllicine, and ajmalidine (Pakrashi et al., 1955). The stem barks of $R$. sellowii have shown anti-inflammatory potential, whereby exposure of human leukocytes to its hydroethanolic extract resulted in inhibition of caseininduced granulocyte migration (Presibella et al., 2003).

Rauvolfia sellowii is a native species of the Atlantic Forest and very little, if any, information, is available about its chemical, pharmacological and botanical aspects. Therefore, the aim of this work was to describe the pharmacognostic characteristics of the young stems and the stem barks, focusing mainly on their anatomical details, to identify parameters that could be used for quality control of the plant drug, contributing to the description of this species widely used by the population.

\section{MATERIAL AND METHODS}

Samples of young stems and stem barks of Rauvolfia sellowii were collected in Curitiba, Parana State, Brazil, at coordinates $25^{\circ} 26^{\prime} \mathrm{S}$ and $49^{\circ} 16^{\prime} \mathrm{O}$ and $923 \mathrm{~m}$ elevation, in January 2009. A voucher sample has been deposited at the Herbarium of the Municipal Botanical Museum of Curitiba under the protocol MBM 348509.

Fragments of young stems, $5-20 \mathrm{~cm}$ of the stem apex, and of stem barks were collected and fixed in FAA70 (Johansen, 1940) and stored in ethanol 70\% (Berlyn, Mi- ksche, 1976). The fixed material was embedded in glycol methacrylate (Leica Historesin $\AA$ ) by the inclusion technique, and sectioned in a rotary microtome Olympus CUT 4055. The slides were then stained with toluidine blue (Beçak, Paulete, 1976; Kraus, Arduin, 1997). The results were registered using photomicrographs on a photonic microscope Olympus BX-40 coupled to a PM-20 control unit, and by schematic drawings.

Microchemical assays to identify cell structures and compounds were performed according to Berlyn and Miksche (1976) and Oliveira and colleagues (1991). Sulphuric acid was used to confirm calcium oxalate crystals, iron chloride for phenolic compounds, phloroglucine hydrochloride for lignin, iodine glycerin for starch and Sudam III for lipophilic compounds.
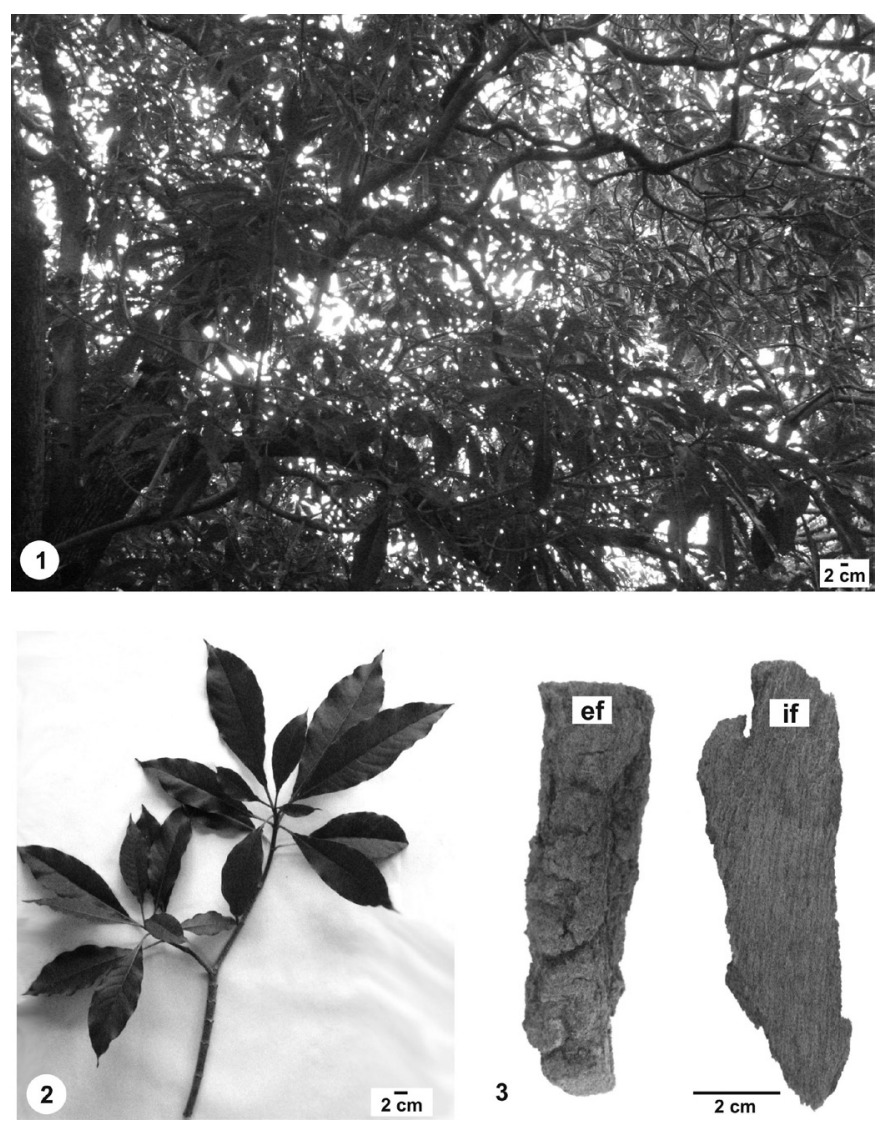

FIGURES 1-3 - Rauvolfia sellowii Müll. Arg. 1. General aspects of the tree. 2. A vegetative branch showing the aspects of the leaves. 3. Fragments of stem bark, emphasizing its external (ef) and internal faces (if).

\section{RESULTS}

At the level of the stems analyzed (Figures 4 and 5), the epidermis remains in the bark, in a detachment phase (Figure 6). In the transverse section, the epidermis has one 
layer of cells coated by a fairly thick cuticle. The epidermal cells are elongated in periclinal direction. Because of the broad circumference of the stems, the phellogen is situated in the cortical layers. It forms the suber in the direction of the periphery, which consists of many cell layers, with suberified walls. Underneath the phellogen, is the phelloderm and the collenchyma with 3-4 cell layers. In the cortex, cells with irregular shapes and sizes with thin walls, and many laticiferous ducts and fibers can be seen (Figure 7).

There is an incomplete sclerenchymatic sheath, consisting of several groups of fibers and stone cells in the initial stage of lignification, with thick walls, surrounding the vascular system (Figures 4, 8 and 9). The external phloem is formed by sieve elements and parenchymatic cells, forming a continuous cylinder around the xylem, being transversed by narrow rays (Figures 4 and 8). The xylem is totally lignified, formed by tracheary elements arranged in rows, with many fibers and parenchymatic cells among them, separated by narrow parenchymatic rays (Figures 8,10 and 12). The internal phloem is arranged in groups, side by side, of sieve elements and parenchymatic cells (Figures 5 and 12). The pith consists of parenchymatic cells with thin walls (Figures 12 and 13).

Many laticiferous ducts are also present in the phloem and pith (Figure 13). Many calcium oxalate druses and prisms are found in the pith (Figures 11 and 12). Idioblasts with phenolic content are situated in the cortex, phloem and pith (Figures 7, 12 and 13). Many amyloplasts are found in the xylem.

The plant drug consists of dried barks of $R$. sellowii (Figure 3). The most relevant microscopic features that characterize the drug include several layers of suber composed of flattened cells, many layers of cortical parenchyma with cells of irregular shapes and sizes, and below this, an incomplete sclerenchymatic sheath formed by many stone cells and fibers, totally lignified as well as the external phloem. Phenolic idioblasts and laticiferous ducts are also visible in the cortical layer of the bark (Figure 14). These aspects are similar to the barks of the fresh plant.

\section{DISCUSSION}

The narrow association of the stems with the leaves makes it the most complex axis of the plant. Depending on the developmental stage of the vegetal, the stems can present structures with primary and secondary growth (Esau, 1974). The internal organization of the stem in the secondary structure of Rauvolfia sellowii allows distinguishing of the coating system, cortical region, vascular cylinder, and medullary region.

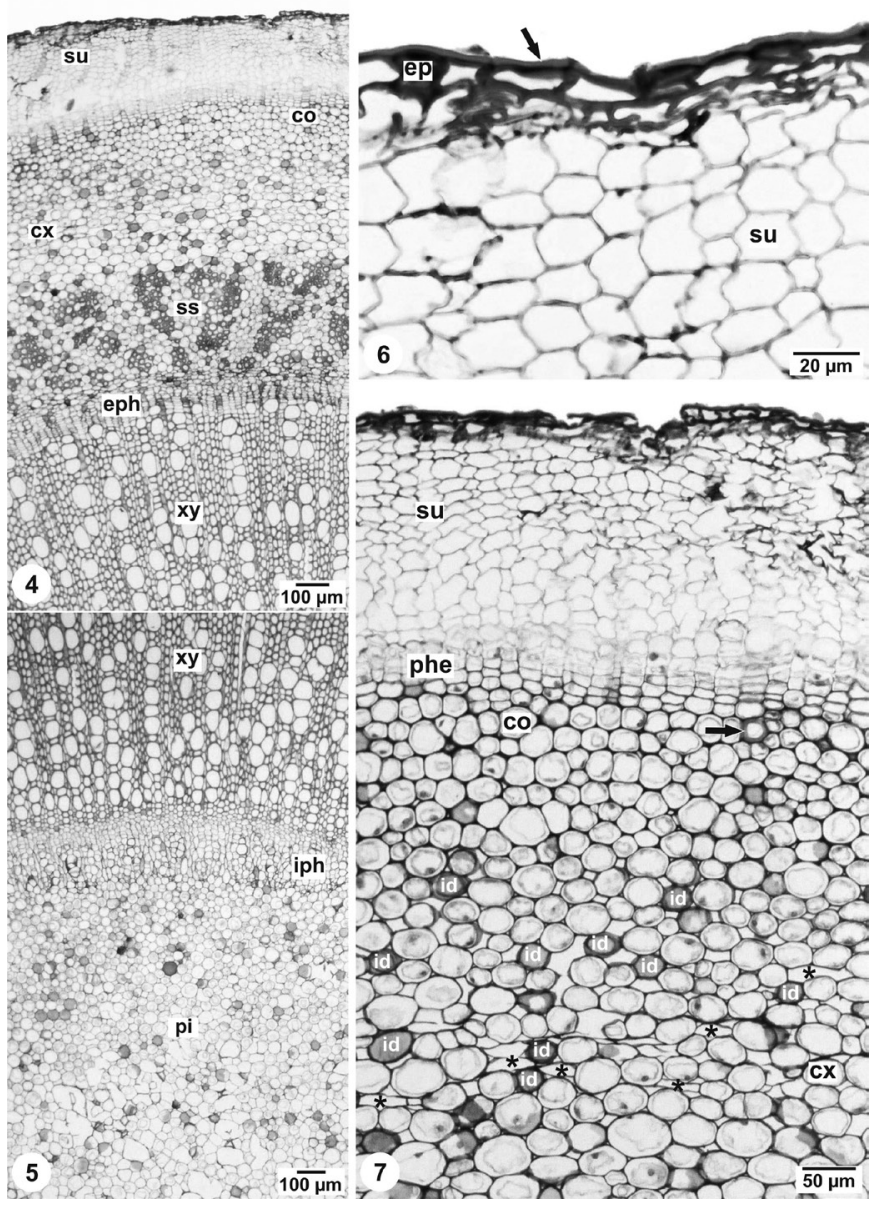

FIGURES 4-7 - Rauvolfia sellowii Müll. Arg. - young stem transverse section: $\mathbf{4}$ and $\mathbf{5}$. General organization of the stem. $\mathbf{6}$. Details of the coating system (arrow - cuticle). 7. Details of the bark (arrow - fiber). Abbreviations: collenchyma (co), cortex (cx), sclerenchymatic sheath (ss), epidermis (ep), external phloem (eph), idioblasts (id), internal phloem (iph), laticiferous ducts (asterisk), phellogen (phe), pith (pi), suber (su) and xylem (xy).

The epidermis, whose main function is coating, is the most extensive system of the vegetal organs, generally formed by only one layer of cells. In organs with secondary growth, the epidermis is replaced by peridermis, which is a protector system that substitutes the external tissues of the stems and roots, and consists of phellogen, suber, and phelloderm (Alquini et al., 2006). The phellogen makes up the suber externally and some layers of phelloderm internally. The suber consists of several layers of cells, without intercellular spaces and with suberified walls, which confer protective properties. The phelloderm consists of active parenchyma cells, generally with 3-4 layers (Cutter, 1986; Mazzoni-Viveiros, Costa, 2006). In the Apocynaceae family, the peridermis consists of cells with thin or sclerified walls, and can have crystals (Metcalfe, Chalk, 1950). In R. sellowii, the epidermis still 

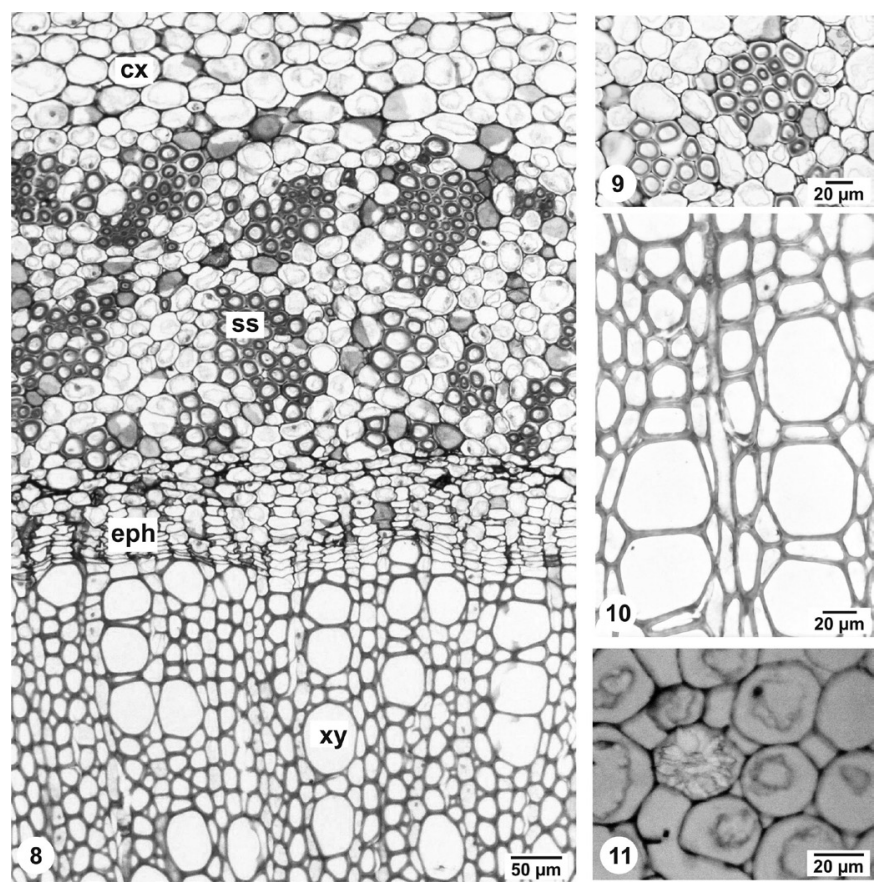

FIGURES 8-11 - Rauvolfia sellowii Müll. Arg. - young stem transverse section: 8. Details of the stem. 9. Details of the incomplete sclerenchymatic sheath. 10. Details of the xylem. 11. Calcium oxalate druse. Abbreviations: cortex (cx), external phloem (eph), sclerenchymatic sheath (ss), and xylem (xy).
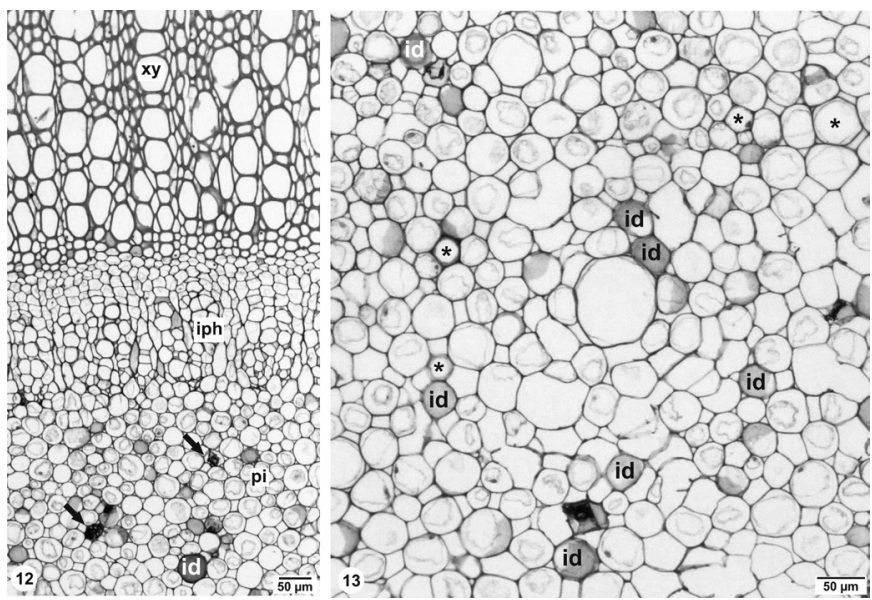

FIGURES 12-13 - Rauvolfia sellowii Müll. Arg. - young stem transversal section: 12. Details of xylem, internal phloem and pith. 13. Details of the pith. Abbreviations: idioblasts (id), internal phloem (iph), laticiferous ducts (asterisks), calcium oxalate crystals (arrows), pith (pi) and xylem (xy).

remains, but a suberified peridermis formed underneath the epidermis is evident, and the phellogen is situated within the cortical layers.

In the Apocynaceae, the vascular system is typically bi-collateral in stems, with the internal phloem always present, forming a continuous ring along the xylem or

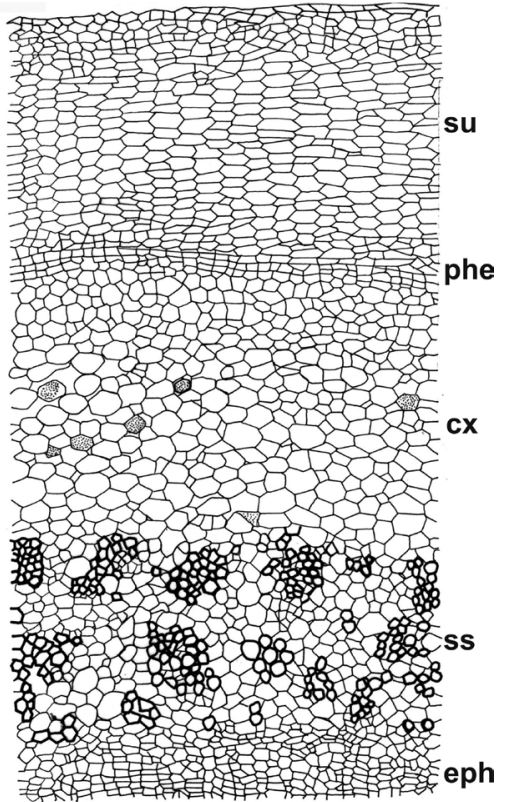

FIGURE 14 - Schema of the stem bark of R. sellowii. Abbreviations: cortex (cx), external phloem (eph), laticiferous ducts (dotted cells), phellogen (phe) and sclerenchymatic sheath (ss).

isolated bundles at the border of the pith, while the xylem forms a continuous cylinder, transversed by narrow rays (Metcalfe, Chalk, 1950; Cronquist, 1981). These remarkable characteristics were observed in $R$. sellowii.

Small prismatic crystals and druses often distributed in the parenchymatic tissues are also characteristics of the Apocynaceae family (Metcalfe, Chalk, 1950; Cronquist, 1981). These crystals are common in unlignified tissues (Metcalfe, Chalk, 1950), and were found in the medullary region of $R$. sellowii, as observed in other species of the family, such as Himatanthus sucuuba (Spruce ex Müll. Arg.) Woodson, Forsteronia glabrescens Müll. Arg. (Larrosa, 2004) and Plumeriopsis ahouai (L.) Rusby \& Woodson (Costa, Costa, 1980).

The starch grains, stored in amyloplasts, can be found in all of the parenchymatic tissues such as cortex and pith, as well as in the vascular tissues (Esau, 1974; Cutter, 1986; Mauseth, 1988). In R. sellowii, the presence of many amyloplasts in the xylem was observed as seen in the apotracheal parenchyma and medullary rays of $P$. ahouai (Costa, Costa, 1980).

The fibers are long, generally found in groups, with secondary walls of variable thickness, which have the main function of sustaining the plant, conferring rigidity and flexibility to the structures (Esau, 1974; Costa et al., 2006; Scatena, Scremin-Dias, 2006). The fibers can be present in the xylem and phloem, as a sheath associated with the vascular bundles, or in the parenchymatic tissues of the 
pith or cortex (Cutter, 1986). In R. sellowii, fibers at an initial stage of lignification were observed in an incomplete sclerenchymatic sheath, surrounding the vascular system. Since ontogenic studies have not been performed, it cannot be determined whether the sheath is of pericycle origin. These fibers can be also of phloem origin. In the region of the sclerenchymatic sheath of $R$. sellowii, the presence of thick-walled stone cells has been described. Metcalfe and Chalk (1950) reported the existence of isolated or grouped stone cells in the primary cortex and in the phloem of some species of the family.

In R. sellowii, fibers at the initial stage of lignification were found sparsely spread throughout the cortex. In the family it is common to observe the presence of unlignified, mucilaginous fibers known as white cellulosic fibers. These are isolated or in rings or bundles in the pericycle, with concentrically-bound walls (Metcalfe, Chalk, 1950; Cronquist, 1981). These mucilaginous fibers absorb a large amount of water and can tumefy, helping in the torsion mechanism of the vegetal (Scatena, Scremin-Dias, 2006).

Idioblasts containing phenolic compounds and laticiferous ducts were found in the cortex, phloem and pith of $R$. sellowii. Metcalfe and Chalk (1950) and Mauseth (1988) reported that laticifers are always present in the stems of Apocynaceae and are generally situated in the cortex, pericycle, phloem, pith and sometimes in the medullary rays. The laticifers are universal characteristics of the family and are generally associated with vascular bundles, related mainly to the phloem. Latex traces can be detected in the laticifers of the species of the genus Himatanthus, Plumeria and Rauvolfia, that contain bright yellow granular content (Metcalfe, Chalk, 1950; Cutter, 1986). In Apocynaceae, the laticifers are generally larger than the surrounding cells, having prominent nucleus, dense cytoplasm, and a polygonal or circular shape in transverse section, without starch grains inside, akin to those verified in another species of the family (Larrosa, 2004).

The dried barks of $R$. sellowii, from a pharmacognostic point of view, are considered as plant drug. In plants, the anatomical structure of the stem is an important tool for diagnosis and can be a key aid in vegetal identification (Mauseth, 1988). The stem is defined as the group of tissues and systems located externally to the cambium (merystematic tissue comprising the vascular system) in the stems and roots. Therefore, the stem is composed of suber, phellogen, phelloderm, cortex and necessarily by the phloem. On the other hand, the set of systems located internally to the cambium in stems and roots, provided with secondary growth, is known as wood. The central region of the wood can contain tissues that do not belong to the xylem, such as medullary parenchyma and internal phloem (Oliveira et al., 1991).

The microscopic characteristics common to the bark of $R$. sellowii, in secondary growth, are several layers of suber and cortical parenchyma, followed by groups of stone cells and fibers, totally lignified, in a sheath surrounding the external phloem, besides the presence of laticiferous ducts in the cortical region, calcium oxalate crystals in the pith and phenolic idioblasts in the cortex and pith. According to Esau (1974) and Scatena, as well as Scremin-Dias (2006), the stone cells are sclereids that are found isolated or in sparse groups, and can be present in all of the fundamental systems of the plant, but develop mainly in the cortex and stem bark. These cells have thick secondary walls, are highly lignified and do not constitute a specific tissue, being found in fairly extensive layers or forming clusters of cells. According to Mauseth (1988), the process of sclerefication often result in a more rigid bark, which does not stand out easily from the tree. Thick barks are the result of continuous circumferential expansion of secondary growth, stretching them tangentially and forming deep cracks and depressions in the surface, externally visible in $R$. sellowii.

The anatomical characteristics observed in young stems and stem barks of $R$. sellowii, such as laticiferous ducts, calcium oxalate druses, internal phloem, beyond fibers and stone cells in a sclerenchymatic sheath, when analyzed in conjunction, contribute to the identification of this medicinal plant and provide valuable information that can serve as quality control parameters of the plant drug.

\section{ACKNOWLEDGEMENTS}

The authors would like to extend their thanks to biologist Osmar dos Santos Ribas at the Herbarium of Municipal Botanical Museum of Curitiba, for identifying the plant material, to the Laboratory of Structural Botany at the Department of Botany, UFPR, and to Nilson Belém Filho, for slide preparation. LCB and CAMS thank CAPES and CNPq, respectively, for the scholarship.

\section{REFERENCES}

ALQUINI, Y.; BONA, C.; BOEGER, M.R.T.; COSTA, C.G.; BARROS, C.F. Epiderme. In: APPEZZATO-DA-GLÓRIA, B.; CARMELLO-GUERREIRO, S.M. (Orgs.). Anatomia vegetal. Viçosa: Editora da UFV, 2006. p.87-108.

BATISTA, C.V.F.; SCHRIPSEMA, J.; VERPOORTE, R.; RECH, S.B.; HENRIQUES, A.T. Indole alkaloids from Rauwolfia sellowii. Phytochemistry, v.41, p.969-973, 1996. 
BEÇAK, W.; PAULETE, J. Técnicas de citologia e histologia. Rio de Janeiro: Livros Técnicos e Científicos, 1976. v.1, $305 \mathrm{p}$.

BERLYN, G.P.; MIKSCHE, J.P. Botanical microtechnique and cytochemistry. Ames: Iowa State University, 1976. 326 p.

CAMPBELL, J.I.A.; MORTENSEN, A.; MOLGAARD, P. Tissue lipid lowering-effect of a traditional Nigerian antidiabetic infusion of Rauwolfia vomitoria foliage and Citrus aurantium fruit. J. Ethnopharmacol., v.104, p.379-386, 2006.

CANCELIERI, N.M.; VIEIRA, I.J.C; SCHRIPSEMA, J.; MATHIAS, L.; BRAZ-FILHO, R. Darcyribeirine, a novel pentacyclic indole alkaloid from Rauvolfia grandiflora Mart. Tetrahedron Lett., v.43, p.1783-1787, 2002.

CARLOS, L.A. Alcaloides de Rauvolfia grandiflora e Rauvolfia mattfeldiana (Apocynaceae). Campos dos Goytacazes, 2007. 200 p. [Tese de Doutorado. Centro de Ciências Tecnológicas e Agropecuárias. Universidade Estadual do Norte Fluminense Darcy Ribeiro].

COSTA, C.G.; CALLADO, C.H.; CORADIN, V.T.R; CARMELLO-GUERREIRO, S.M. Xilema. In: APPEZZATO-DA-GLÓRIA, B; CARMELLOGUERREIRO, S.M. (Orgs.). Anatomia vegetal. Viçosa: Editora da UFV, 2006. p.129-154.

COSTA, C.G.; COSTA, E.L. Plumeriopsis ahouai (L.) Rusby et Woodson, Apocynaceae. Considerações anatômicas. Arq. Jard. Bot. Rio de Janeiro, v.24, p.117-140, 1980.

CRONQUIST, A. An integrated system of classification of flowering plants. New York: Columbia University Press, 1981. $1262 \mathrm{p}$

CUTTER, E.G. Anatomia vegetal. São Paulo: Roca, 1986. 304 p.

DJERASSI, C.; FISHMAN, J.; GORMAN, M.; KUTNEY, J.P.; PAKRASHI, S.C. Alkaloid studies. XVI. Alkaloids of Rauwolfia tetraphylla L. The structures of tetraphylline and tetraphyllicine. J. Am. Chem. Soc., v.79, p.1217-1222, 1957.

ESAU, K. Anatomia das plantas com sementes. São Paulo: Edgard Blücher, 1974. 293.p.

HANHINEN, P.; LOUNASMAA, M. Revision of the structure of ajmalimine. J. Nat. Prod., v.64, p.686-687, 2001.
HOCHSTEIN, F.A. Alkaloids of Rauwolfia sellowii. J. Am. Chem. Soc., v.77, p.5744-5745, 1955.

JOHANSEN, D.A. Plant microtechnique. New York: McGrawHill, 1940. 523 p.

KATO, L. Estudo fitoquímico de espécies brasileiras de Rauvolfia (Apocynaceae). Campinas, 2001. 213 p. [Tese de Doutorado. Instituto de Química. Universidade Estadual de Campinas].

KATO, L.; BRAGA, R.M.; KOCH, I.; KINOSHITA, L.S. Indole alkaloids from Rauvolfia bahiensis A.DC. (Apocynaceae). Phytochemistry, v.60, p.315-320, 2002.

$\mathrm{KOCH}, \mathrm{I}$. Estudos das espécies neotropicais do gênero Rauvolfia L. (Apocynaceae). Campinas, 2002. 301 p. [Tese de Doutorado. Instituto de Biologia. Universidade Estadual de Campinas].

KRAUS, J. E.; ARDUIN, M. Manual básico de métodos em morfologia vegetal. Rio de Janeiro: Edur, 1997. 198 p.

LACOBUCCI, G.; DEULOFEU, V. Alkaloids from Rauwolfia schueli. J. Org. Chem., v.22, p.94-95, 1957.

LARROSA, C.R.R. Morfoanatomia foliar e caulinar de espécies medicinais de Apocynaceae: Himatanthus sucuuba (Spruce) Woodson, Mandevilla coccinea (Hook. \& Arn.) Woodson e Forsteronia glabrescens Müll. Arg. Curitiba, 2004. 89p. [Dissertação de Mestrado. Departamento de Farmácia. Universidade Federal do Paraná].

MANDINAVEITIA, A.; VALENCIA, E.; BERMEJO, J.; GONZALEZ, A.G. Indole alkaloids from Rauwolfia sprucei. Biochem. Syst. Ecol., v.23, p.877, 1995.

MAUSETH, J.D. Plant anatomy. Menlo Park: Benjamin/ Cummings, 1988. 560 p.

MAZZONI-VIVEIROS, S.C.; COSTA, C.G. Periderme. In: APPEZZATO-DA-GLÓRIA, B.; CARMELLOGUERREIRO, S.M. (Orgs.). Anatomia vegetal. Viçosa: Editora da UFV, 2006. p.237-263.

METCALFE, C.R.; CHALK, L. Anatomy of the dicotyledons: leaves, stem and wood in relation to taxonomy with notes on economic uses. Oxford: Clarendon, 1950. v.2, 1500 p.

OLIVEIRA, F.; AKISUE, G.; AKISUE, M.K. Farmacognosia. São Paulo: Atheneu, 1991. 221 p. 
PAKRASHI, S.C.; DJERASSI, C.; WASICKY, R.; NEUSS, N. Alkaloid studies. IX. Rauwolfia alkaloids. IV. Isolation of reserpine and other alkaloids from Rauwolfia sellowii Muell. Argov. J. Am. Chem. Soc., v.77, p.6687-6689, 1955.

PESEWU, G.A.; CUTLER, R.R., HUMBLER, D.P. Antibacterial activity of plants used in traditional medicines of Ghana with particular reference to MRSA. J. Ethnopharmacol., v.116, p.102-111, 2008.

PRESIBELLA, M.M.; SANTOS, C.A.M.; WEFFORTSANTOS, A.M. Influência de extratos hidroetanólicos de plantas medicinais sobre a quimiotaxia de leucócitos humanos. Rev. Bras. Farmacogn., v.13, p.75-82, 2003.

QUINTANS-JÚNIOR, L.J.; SILVA, D.A.; SIQUEIRA, J.S.; SOUZA, M.F.V.; ALMEIDA, R.N.; SILVA-JÚNIOR, R.G.C. Anticonvulsivant properties of the total alkaloid fraction of Rauvolfia ligustrina Roem. et Schult. in male mice. Rev. Bras. Farmacogn., v.17, p.176-180, 2007.

RASTOGI, N.; ABAUL, J.; GOH, K.S.; DEVALLOIS, A.; PHILOGĖNE, E.; BOURGEOIS, P. Antimycobacterial activity of chemically defined natural substances from the Caribbean flora in Guadeloupe. FEMS Immunol. Med. Microbiol., v.20, p.267-273, 1998.
RECH, S.B.; BATISTA, C.V.F.; SCHRIPSEMA, J.; VERPOORTE, R.; HENRIQUES, A.T. Cell cultures of Rauwolfia sellowii: growth and alkaloid production. Plant Cell Tissue Organ. Cult., v.54, p.61-63, 1998.

SCATENA, V.L.; SCREMIN-DIAS, E. Parênquima, Colênquima e Esclerênquima. In: APPEZZATO-DA-GLÓRIA, B.; CARMELLO-GUERREIRO, S.M. (Orgs.). Anatomia vegetal. Viçosa: Editora da UFV, 2006. p.109-128.

SILVA, G.L.C.; GAERTNER, P.; MARSON, P.G.; SCHWARZ, E.A.; SANTOS, C.A.M. An ethno-pharmacobotanical survey in Salto Caxias Hydroelectric Power Plant in Paraná State, Brazil, before the flooding. Lat. Am. J. Pharm., v.23, p.148-153, 2004.

TONA, L.; KAMBU, K.; NGIMBI, N.; CIMANGA, K.; VLIETINCK, A.J. Antiamoebic and phytochemical screening of some Congolese medicinal plants. $J$. Ethnopharmacol., v.61, p.57-65, 1998.

Received for publication on $27^{\text {th }}$ June 2009 Accepted for publication on $09^{\text {th }}$ March 2010 